\title{
Effect of the microbial lipopeptide on tumor cell lines: apoptosis induced by disturbing the fatty acid composition of cell membrane
}

\author{
Xiangyang Liu ${ }^{1,2}$, Xinyi Tao ${ }^{1}$, Aihua Zou ${ }^{1}$, Shizhong Yang $^{1}$, Lixin Zhang ${ }^{2}{ }^{\bowtie}$, Bozhong Mu $^{1 凶}$ \\ ${ }^{1}$ State Key Laboratory of Bioreactor Engineering and Institute of Applied Chemistry, East China University of Science and \\ Technology, Shanghai 200237, China \\ 2 Institute of Microbiology, Chinese Academy of Sciences, Beijing 100190, China \\ \ Correspondence: bzmu@ecust.edu.cn (B. Mu), zhanglixin@im.ac.cn (L. Zhang) \\ Received April 30, 2010 Accepted May 25, 2010
}

\section{ABSTRACT}

Microbial lipopeptides play an important role in apoptosis induction of tumor cells. However, there is little knowledge about the relationship between apoptosis induction and membrane fatty acids. The present study focused on the effects of lipopeptides produced by Bacillus subtilis HSO121 on Bcap-37 cell lines. 3-(4, 5dimethylthiazol-2-yl)-2, 5-diphenyl (MTT) colorimetric assay and surface tension measurements, showed that the critical micelle concentration (CMC) was a critical level for the inhibitory activity of lipopeptides on the growth of Bcap-37 cells. Under the CMC, the order of least to greatest cytotoxicity effect on cancer cell lines by lipopeptides is $\mathrm{C}_{13}$-lipopeptide $<\mathrm{C}_{14}$-lipopepitde $<\mathrm{C}_{15^{-}}$ lipopeptide. Above CMC, all lipopeptides directly exert cytolytic activity. The flow cytometric analysis and Hoechst33258 staining experiments confirmed the apoptosis of Bcap-37 cell lines induced by lipopeptides in a dose-dependent manner. This apoptosis was associated with a significant decrease of the unsaturated degree of the cellular fatty acids of Bcap-37 cell lines due to the changes in the cellular fatty acids composition induced by the lipopeptide treatment. These results indicated that disturbance of the cellular fatty acid composition of breast cancer cell lines were related to in the cell apoptosis. Furthermore, significant difference in $\mathbf{I C}_{50}$ values of tumor cells and normal cell showed that the lipopeptide exerted selective cytotoxicity on the cancer cells. Thus HSO121 lipopeptides may have potential applications as an anticancer leads.

KEYWORDS Bacillus subtilis, lipopeptide, antitumor activity, membrane fatty acid, apoptosis

\section{INTRODUCTION}

Breast cancer has become a global concern (Singletary, 2008). Efforts in the field of chemotherapeutic treatments have led to the discovery of tamoxifen, cytotoxics paclitaxel and docetaxel, all of which show severe side effects (Marsh and McLeod, 2007). Furthermore, the emergence of resistant tumor cells calls for novel anticancer compounds with unique modes of action. These threats have prompted investigation into new targets for cancer action including: cellular efflux pumps, lipopolysaccharide synthesis, mRNA and membrane fatty acid synthesis (Menendez et al., 2005; Dai et al., 2008; Kuo, 2009). Cellular membranes constitute a particularly appealing target because resistance to membrane-active anticancer agents requires major changes in membrane structure, of which most structural elements are conserved (Vaara, 1992; Savage et al., 2002; Michel and Bakovic, 2007). Therefore, investigations on membrane-active natural products play an important role in dissecting fundamental biologic processes of tumor cells and, therefore, the further development of chemotherapeutic antitumor drugs.

Microbial lipopeptides are a class of amphiphilic molecules with fatty acid moieties covalently connected with peptide moieties (Bonmatin et al., 2003). Many of these molecules with membrane active properties play an important role in the apoptosis induction process of tumor cells. For example, surfactin, a cyclic lipopeptide produced by Bacillus subtilis (Arima et al., 1968), is well-known for its antitumor activity on Ehrlich carcinoma tumor cells and LoVo cells (Kameda et al., 1974; Kim et al., 2007). In addition, surfactin can cause membrane leakage through pore formation (Grau et al., 1999), ion channel formation (Sheppard et al., 1991), action as a cation carrier (Sheppard et al., 1991) and detergent like effects (Heerklotz and Seelig, 2001), all of which eventually 
lead to cytotoxic effects. A recent study suggests that cyclic lipopeptides have anti-proliferative effect on K562 cells by inducing apoptosis (Wang et al., 2007). Characterization of lipopeptide structures has revealed surprising diversity and, along with the unique functional groups they possess, point to an encouraging area of anticancer research. However, how the membrane active properties of the lipopeptides contribute to the induced apoptosis of tumor cells is still unknown.

We have found a group of surfactin-like lipopeptides produced by Bacillus subtilis HSO121 (Liu et al., 2007). To explore the anticancer activity of these lipopeptides, we tested their cytotoxicity against Bcap-37 cell lines. To do this we used two approaches. The biologic approach included fluorescent staining and a flow cytometric assay. The chemical methods included measurements of the $\mathrm{CMC}$ (critical micelle concentration) and GC (gas chromatography) analysis of fatty acid composition of the cellular membrane. Furthermore, the effects of lipopeptides on other tumor, as well as normal, cells were also investigated. The results of this study help to further understand the potential functions of lipopeptides in inducing apoptosis in tumor cells and shed light on the potential applications of lipopeptides in the chemotherapy of breast cancer.

\section{RESULTS}

\section{Effect of lipopeptide chain length on cytotoxic activity}

To select the most effective lipopeptides to do the experiments, cytotoxic activities of lipopeptides with different lipid chain lengths were investigated. It showed that the $\mathrm{IC}_{50}$ values of $\mathrm{C}_{13}$-lipopeptide, $\mathrm{C}_{14}$-lipopeptide and $\mathrm{C}_{15^{-}}$ lipopeptide on Bcap-37 cells were $60.81 \pm 0.94 \mu \mathrm{g} / \mathrm{mL}$, $41.26 \pm 9.60 \mu \mathrm{g} / \mathrm{mL}$ and $29.7 \pm 2.44 \mu \mathrm{g} / \mathrm{mL}$, respectively (Fig. 1A).

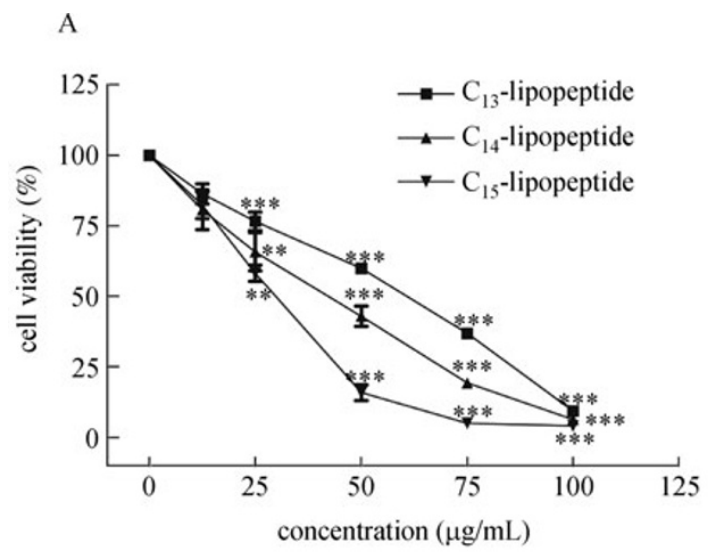

At the concentration of $75 \mu \mathrm{g} / \mathrm{mL}, \mathrm{C}_{15}$-lipopeptide significantly reduced the cell viability to $5.0 \%$, while $\mathrm{C}_{13}$-lipopeptide and $\mathrm{C}_{14}$-lipopeptide reduced the cell viability to $36.9 \%$ and 19.3\%, respectively (Fig. 1B).

\section{Effect of lipopeptide concentrations and treatment time on cytotoxic activity}

$\mathrm{C}_{15}$-lipopeptide was selected for further investigations. The surface tension of a PBS solution of $\mathrm{C}_{15}$-lipopeptide was reduced from $70.1 \mathrm{mN} / \mathrm{m}$ to a constant value of $26.5 \mathrm{mN} / \mathrm{m}$ with the increase of lipopeptide concentration. The CMC of $\mathrm{C}_{15}$-lipopeptide was determined to be $10.2 \mu \mathrm{g} / \mathrm{mL}$ (Fig. 2A). It showed that the inhibitory activity of the lipopeptide on tumor cells was correlated with its interfacial behavior, and the inhibitory concentrations were above the CMC (Fig. 2B).

The cytotoxic effects of lipopeptides on Bcap-37 cells (Fig. 2C) decreased with increasing treatment time when the concentration of the lipopeptide was less than $25 \mu \mathrm{g} / \mathrm{mL}$. This phenomenon was especially obvious for the treatment time of $12 \mathrm{~h}$ and $48 \mathrm{~h}$ (Fig. 2D). At concentrations of $12.5 \mu \mathrm{g} / \mathrm{mL}$ and $25 \mu \mathrm{g} / \mathrm{mL}$, the cytotoxicity of lipopeptides significantly decreased when the treatment time increased from $12 \mathrm{~h}$ to $48 \mathrm{~h}$. However, at a lipopeptide concentration of $75 \mu \mathrm{g} / \mathrm{mL}$, the cytotoxicity activity significantly increased with the treatment time $(12 \mathrm{~h}$ to $48 \mathrm{~h})$.

\section{Observations of morphological changes in Bcap-37 cells}

To study the effects of lipopeptides on the morphology of tumor cells, untreated and treated cells were analyzed by microscope. In the control group, the cells treated with vehicle $(0.1 \%$ DMSO $)$ aggregated in patches. The surface of each cell was convex and the boundaries of cells were well defined. Compared with the control cells, most cells treated with

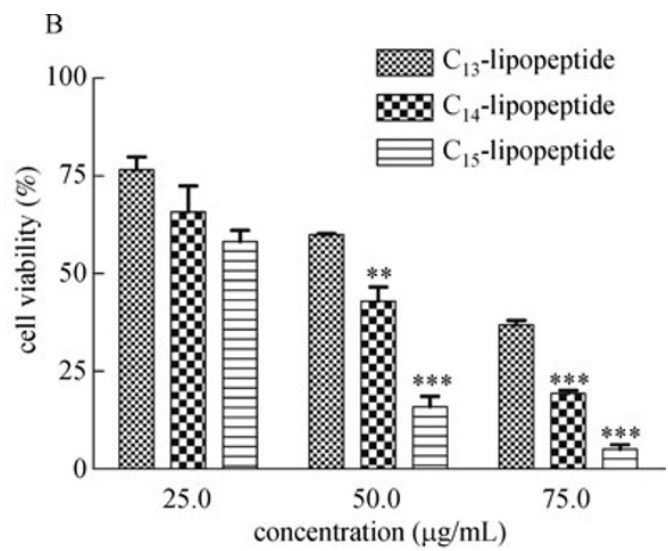

Figure 1. The dose-dependent inhibition of cell viability with various concentrations of the three peptides. (A) Cells treated lipopeptides for $24 \mathrm{~h}$. (Significant differences from untreated control were indicated by ${ }^{* *} P<0.01$; *** $P<0.001$.) (B) Comparison of effects of lipopeptides with different chain lengths. (Significant differences from effects of $\mathrm{C}_{13}$-lipopeptide were indicated by ${ }^{* *} P<$ $0.01{ }^{* * *} P<0.001$.) 


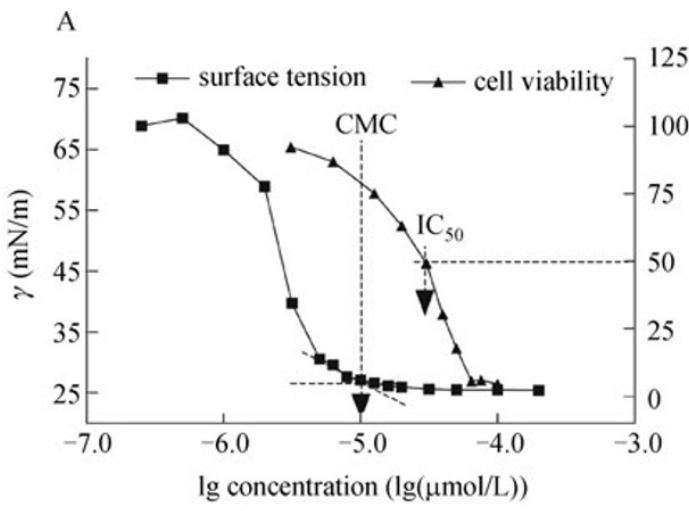

$$
\mathrm{C}
$$

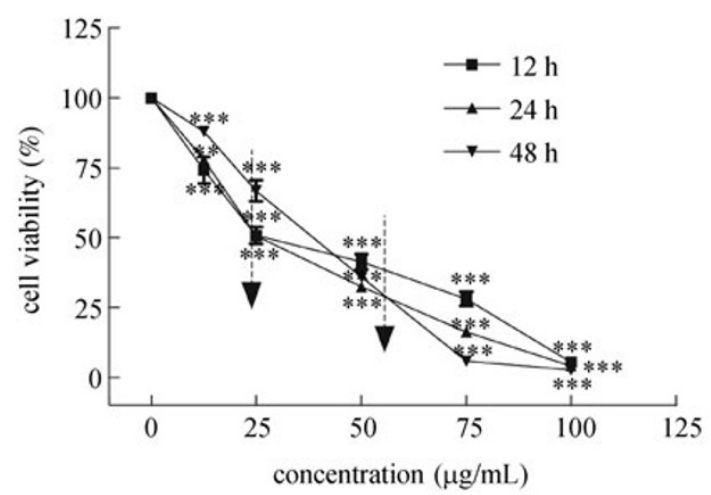

B

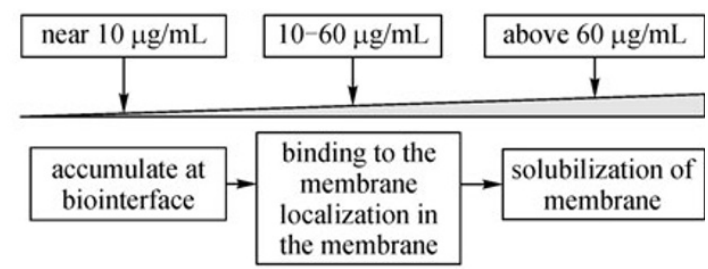

D

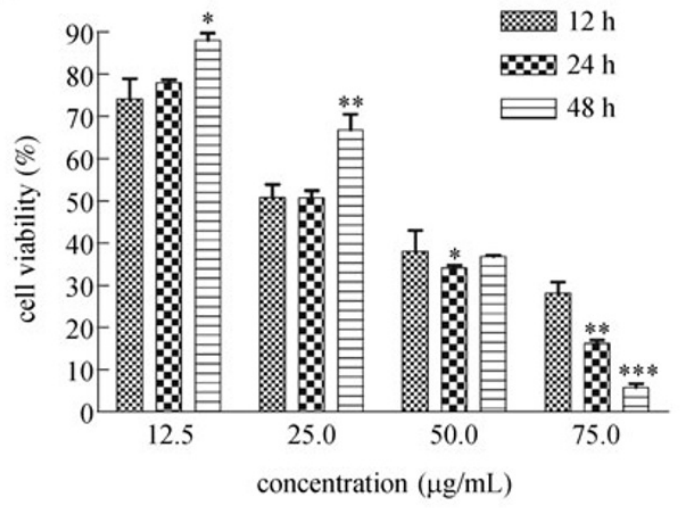

Figure 2. The relationship of surface tension and time on cell viability. (A) The relation between lipopeptide concentrations, surface tension and cell viability. (B) Deduced action modes of the lipopeptide on tumor cell membranes. The concentrations 10 (CMC), 10-60 and $>60 \mu \mathrm{g} / \mathrm{mL}$ represented less-inhibitory, inhibitory and killing concentrations, respectively. (C) Effects of treatment time on the cytotoxicity of lipopeptides (Significant differences from control: ${ }^{* *} P<0.01,{ }^{* * *} P<0.001$.) (D) Effects of treatment time on the cell viability at different concentrations. (Significant differences from treatment time of $12 \mathrm{~h}$ : ${ }^{* *} P<0.01,{ }^{* * *} P<0.001$.)

$75 \mu \mathrm{g} / \mathrm{mL}$ lipopeptides were of a shrunken size and cell membranes were blebbing.

Staining with Hoechst 33258 showed fragmentation and condensation of chromatin in the cells treated for $24 \mathrm{~h}$ with $75 \mu \mathrm{g} / \mathrm{mL}$ lipopeptides (Fig. 3B). Control cells (Fig. 3A) which exhibited a normal nuclear morphology were characterized by a diffuse chromatin structure and therefore light staining.

\section{Effects of lipopeptide on the population of Bcap-37 hypodiploid}

To verify whether the lipopeptides induced apoptosis in Bcap37 cells, flow cytometric analysis was performed to detect hypodiploid cells, which were identified as giving DNA fluorescence in the sub-diploid regions. Ten thousand cells in each sample were analyzed and the percentage of apoptotic cell accumulation in the sub-G1 peak was calculated. As shown in Fig. 4B-E, the sub-G0/1 population in lipopeptide-treated groups increased with the concentration of the lipopeptide. After a $24 \mathrm{~h}$ incubation with
$20,30,40$ and $60 \mu \mathrm{g} / \mathrm{mL}$ lipopeptides, the percentages of hypodiploid cells were $1.49 \pm 0.93 \%, 2.05 \pm 0.27 \%, 4.19 \pm$ $0.53 \%$ and $18.31 \pm 0.72 \%$, respectively (Fig. 4F).

\section{Lipopeptide induced changes in lipid composition of cell membranes}

GC/MS analysis of the membrane fatty acids of Bcap-37 cells was performed to investigate the effects of lipopeptides on tumor cellular membranes. It showed that the total amount of fatty acids was significantly decreased in a dose-dependent manner after the tumor cells were treated with lipopeptides (Fig. 5). Compared to the amounts of fatty acids in the negative control group, the amounts of those in the positive control groups treated with $30 \mu \mathrm{g} / \mathrm{mL}$ and $60 \mu \mathrm{g} / \mathrm{mL}$ lipopeptides were decreased by $51.2 \%$ and $67.1 \%$, respectively.

To explore the effects of lipopeptides on membrane disturbance, the lipid composition of cancer cell membranes 

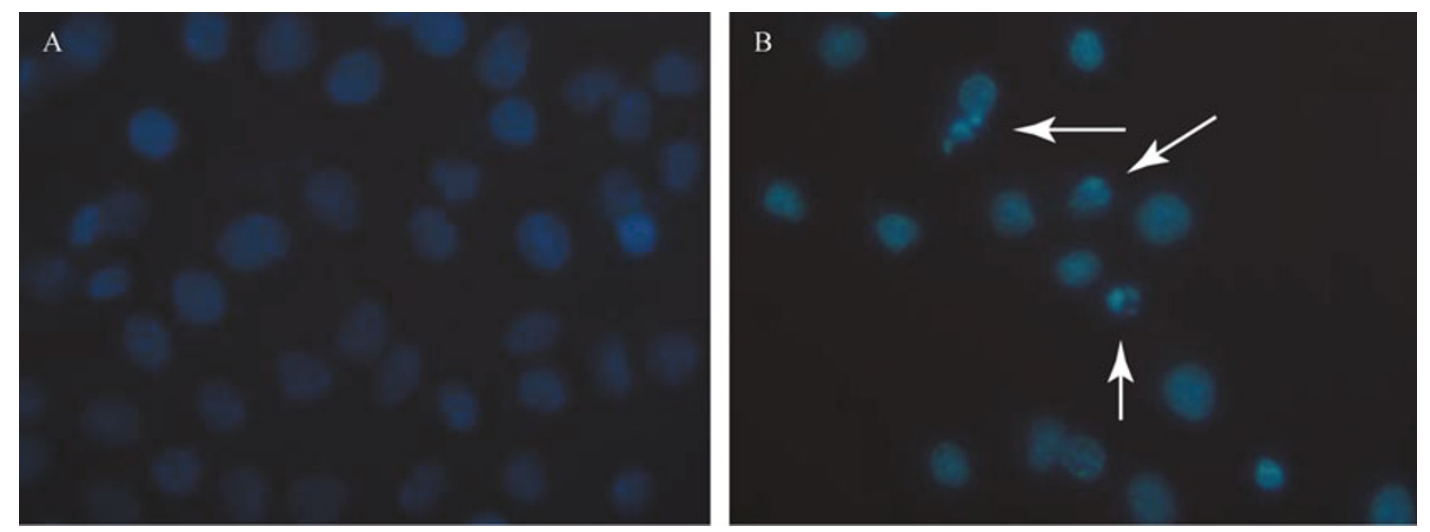

Figure 3. The fluorescent staining of nuclei in Bcap-37 cells by Hoechst 33258 . Cells were treated with or without $75 \mu \mathrm{g} / \mathrm{mL}$ $\mathrm{C}_{15}$-lipopeptide for $24 \mathrm{~h}$. Cells with condensed and fragmented nuclei and apoptotic bodies (arrows) were observed in the lipopeptide-treated cells $(B)$, but not in the cells with control treatment (A). Magnification: $400 \times$.
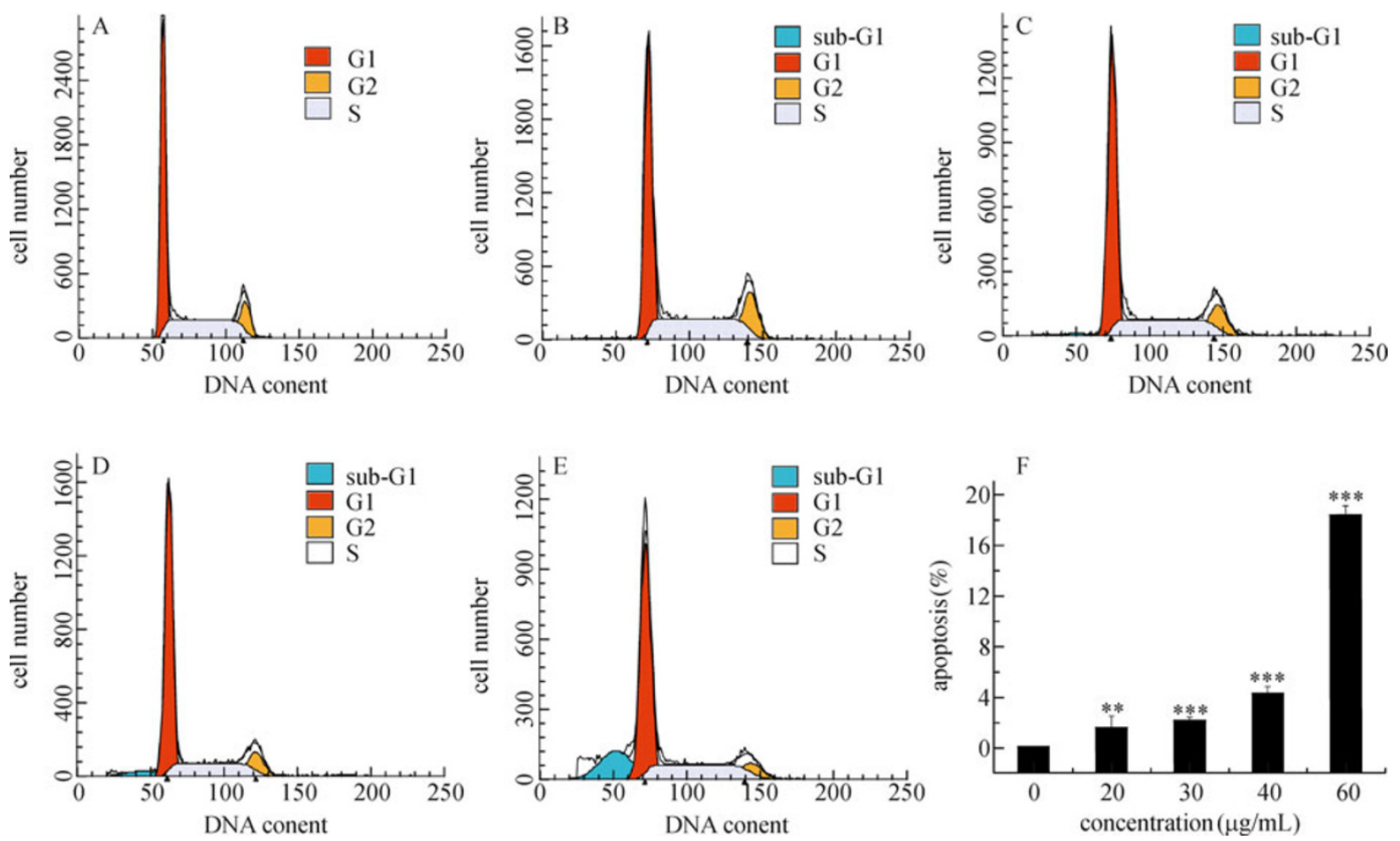

Figure 4. Analysis of the population of hypodiploid cells in Bcap-37 cells by flow cytometry. (A) Representative of the profiles of cell cycle distribution in three independent experiments per concentration was shown. Bcap-37 cells treated with 0 (A), $20 \mu \mathrm{g} / \mathrm{mL}(B), 30 \mu \mathrm{g} / \mathrm{mL}(C), 40 \mu \mathrm{g} / \mathrm{mL}(\mathrm{D})$ and $60 \mu \mathrm{g} / \mathrm{mL}(E) C_{15}$-lipopeptide for $24 \mathrm{~h}$. (F) The percentage of hypodiploid cells after staining with propidium iodide. (Significant differences from control: ${ }^{* *} P<0.001$.)

was examined (Table 1). The fatty acids $\mathrm{C}_{16: 1}, \mathrm{C}_{18: 1}$ and $\mathrm{C}_{20: 4}$ showed a decrease of $56.6 \%, 13.6 \%$ and $45.2 \%$, respectively, in cancer cell lines after being cultured for $24 \mathrm{~h}$ in the medium containing $60 \mu \mathrm{g} / \mathrm{mL}$ lipopeptides. The changes in lipid composition induced by the lipopeptide were probably consequences of membrane permeabilization due to the perturbing action of lipopeptides. In addition, the unsaturated degree (Geiser et al., 1994) of cellular fatty acids treated with the $30 \mu \mathrm{g} / \mathrm{mL}$ and $60 \mu \mathrm{g} / \mathrm{mL}$ lipopeptides was decreased from $29.3 \%$ to $28.3 \%$ and $23.4 \%$, respectively, which indicated that the physiologic properties of membranes, such as fluidity and cellular functions, may be changed (Hagve, 1988). 


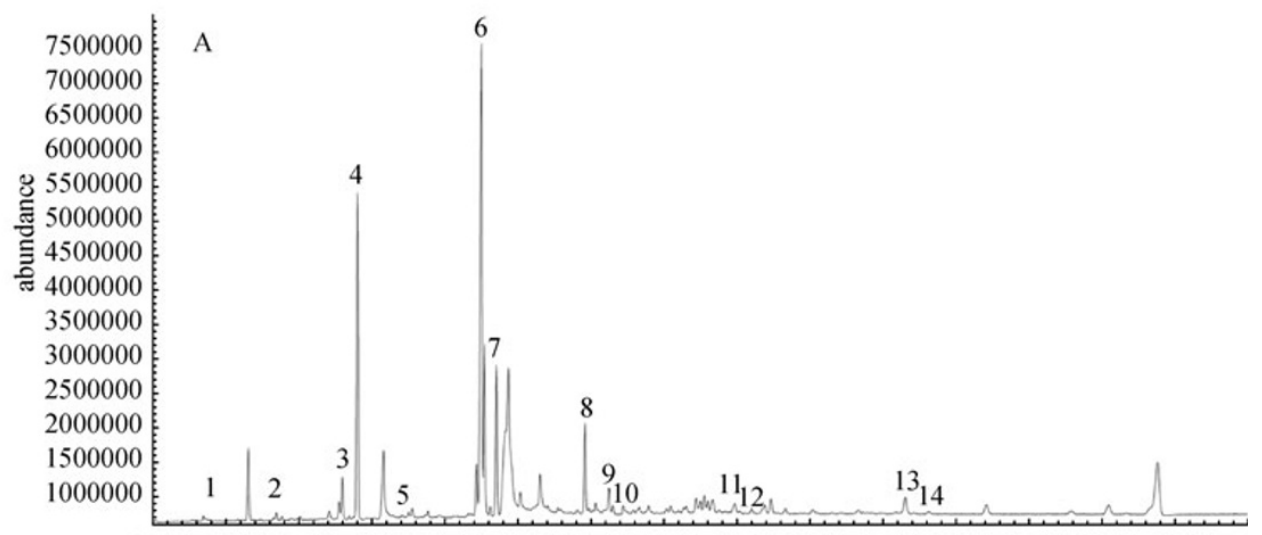

15.0016 .0017 .0018 .0019 .0020 .0021 .0022 .0023 .0024 .0025 .0026 .0027 .0028 .0029 .00 time (h)
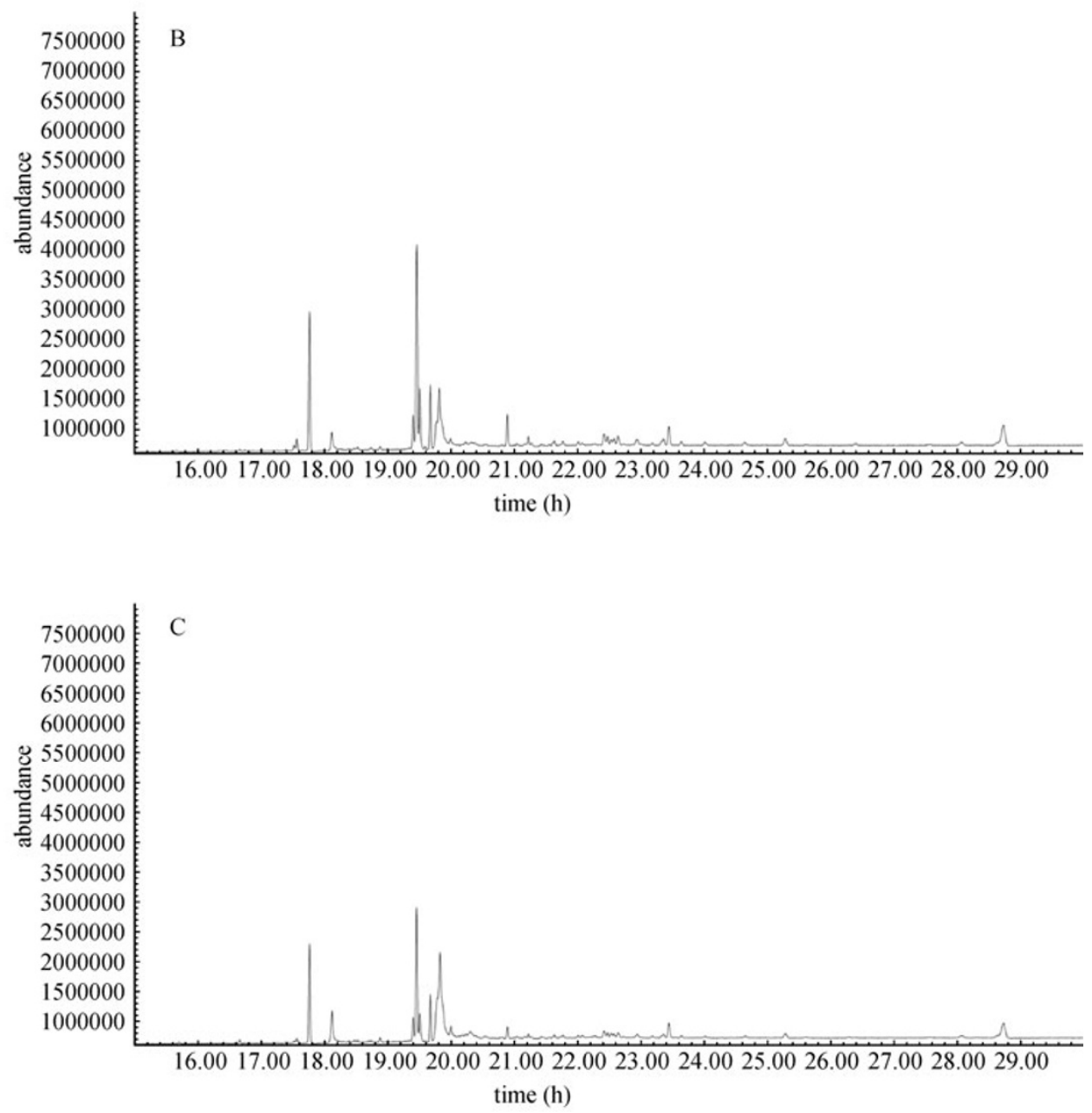

Figure 5. GC/MS analysis of fatty acid composition of membrane lipids of Bcap-37 cells. (A) Control cells; (B) and (C) Cells were treated with $30 \mu \mathrm{g} / \mathrm{mL}$ (B) and $60 \mu \mathrm{g} / \mathrm{mL}$ (C) lipopeptides for $24 \mathrm{~h}$. Each group showed same peaks (peak 1-14 were shown in Table 1). 
Table 1 Effects of $\mathrm{C}_{15}$ lipopeptide on fatty acid composition of membrane lipids

\begin{tabular}{lccccc}
\hline peak & Rt & fatty acid & \multicolumn{3}{c}{ percentage $(\%)$} \\
\cline { 3 - 5 } & & & 0 & $30(\mu \mathrm{g} / \mathrm{mL})$ & $60(\mu \mathrm{g} / \mathrm{mL})$ \\
\hline 1 & 15.68 & $\mathrm{C}_{14: 0}$ & $0.82 \pm 0.029$ & $0.58 \pm 0.058^{\mathrm{a}}$ & $0.45 \pm 0.047^{\mathrm{b}}$ \\
2 & 16.76 & $\mathrm{C}_{15: 0}$ & $0.58 \pm 0.029$ & $0.52 \pm 0.033$ & $0.38 \pm 0.017^{\mathrm{b}}$ \\
3 & 17.58 & $\mathrm{C}_{16: 1}$ & $2.21 \pm 0.005$ & $1.71 \pm 0.052^{\mathrm{b}}$ & $0.96 \pm 0.015^{\mathrm{b}}$ \\
4 & 17.79 & $\mathrm{C}_{16: 0}$ & $49.32 \pm 0.623$ & $48.96 \pm 0.426$ & $50.29 \pm 0.305$ \\
5 & 18.40 & $\mathrm{C}_{17: 0}$ & $0.36 \pm 0.019$ & $0.51 \pm 0.024^{\mathrm{b}}$ & $0.68 \pm 0.010^{\mathrm{b}}$ \\
6 & 19.49 & $\mathrm{C}_{18: 1}$ & $21.63 \pm 0.443$ & $21.27 \pm 0.538$ & $18.68 \pm 0.386^{\mathrm{b}}$ \\
7 & 19.69 & $\mathrm{C}_{18: 0}$ & $20.38 \pm 0.062$ & $21.52 \pm 0.208^{\mathrm{b}}$ & $23.68 \pm 0.282^{\mathrm{b}}$ \\
8 & 20.91 & $\mathrm{C}_{20: 4}$ & $0.84 \pm 0.078$ & $0.76 \pm 0.070$ & $0.46 \pm 0.094^{\mathrm{a}}$ \\
9 & 21.24 & $\mathrm{C}_{20: 1}$ & $0.86 \pm 0.050$ & $0.87 \pm 0.178$ & $0.57 \pm 0.145$ \\
10 & 21.44 & $\mathrm{C}_{20: 0}$ & $0.55 \pm 0.035$ & $0.65 \pm 0.030$ & $0.94 \pm 0.096^{\mathrm{a}}$ \\
11 & 22.97 & $\mathrm{C}_{22: 1}$ & $0.31 \pm 0.007$ & $0.42 \pm 0.036^{\mathrm{a}}$ & $0.38 \pm 0.018^{\mathrm{a}}$ \\
12 & 23.19 & $\mathrm{C}_{22: 0}$ & $0.72 \pm 0.021$ & $0.76 \pm 0.102$ & $1.00 \pm 0.096^{\mathrm{a}}$ \\
13 & 25.30 & $\mathrm{C}_{24: 1}$ & $0.89 \pm 0.060$ & $1.02 \pm 0.105$ & $0.91 \pm 0.030$ \\
14 & 25.62 & $\mathrm{C}_{24: 0}$ & $0.48 \pm 0.046$ & $0.47 \pm 0.073$ & $0.63 \pm 0.092$ \\
\hline
\end{tabular}

a $P<0.01$ versus control.

${ }^{\mathrm{b}} P<0.001$ versus control.

\section{Cytotoxic effects of the lipopeptide on cancer/normal cells}

To explore the therapeutic potential of $\mathrm{C}_{15}$-lipopeptide, it was important to investigate the differential toxicity between tumor cells and normal cells. As shown in Fig. 6 , the $I C_{50}$ values for cell lines B16, Bel-7402, HeLa, Bcap-37, KB-3-1 and Sw1990 cells were $20.8 \pm 1.6 \mu \mathrm{g} / \mathrm{mL}, 36.7 \pm 12.4 \mu \mathrm{g} / \mathrm{mL}, 38.8 \pm$ $4.7 \mu \mathrm{g} / \mathrm{mL}, 29.7 \pm 2.4 \mu \mathrm{g} / \mathrm{mL}, 59.0 \pm 2.7 \mu \mathrm{g} / \mathrm{mL}$ and $59.9 \pm$ $1.7 \mu \mathrm{g} / \mathrm{mL}$, respectively. These results showed that the cytotoxic activity of $\mathrm{C}_{15}$-lipopeptide was cell line specific. Both Bcap-37 cells and B16 cells were very sensitive to the $\mathrm{C}_{15}$-lipopetide. However, the $\mathrm{IC}_{50}$ value for Hacat cells was $100 \mu \mathrm{g} / \mathrm{mL}$.

\section{DISCUSSION}

The interactions of surfactin-like lipopeptides with various cell lines have been studied by many researchers. The $50 \%$ cytotoxic concentrations of surfactin for the adhesive and nonadhesive cell lines were as follows: $\mathrm{ML}, 40 \mu \mathrm{mol} / \mathrm{L}$; 293, $30 \mu \mathrm{mol} / \mathrm{L} ; \mathrm{Hep} 2,42 \mu \mathrm{mol} / \mathrm{L} ; \mathrm{CV} 1,50 \mu \mathrm{mol} / \mathrm{L} ;$ Molt 4/8, $35 \mu \mathrm{mol} / \mathrm{L}$; MT-4, $30 \mu \mathrm{mol} / \mathrm{L}$; and H9, $43 \mu \mathrm{mol} / \mathrm{L}$ (Vollenbroich et al., 1997). The $I_{50}$ of surfactin on LoVo cells was about $60 \mu \mathrm{mol} / \mathrm{L}$ after treated $24 \mathrm{~h}$ (Kim et al., 2007), and in addition, a new cyclic lipopeptide inhibited proliferation in K562 cells with an $\mathrm{IC}_{50}$ value approximately to $30 \mu \mathrm{g} / \mathrm{mL}$ (Wang et al., 2007). Combined with our present work, it can be concluded that surfactin-like lipopeptides at a concentration of 20
A

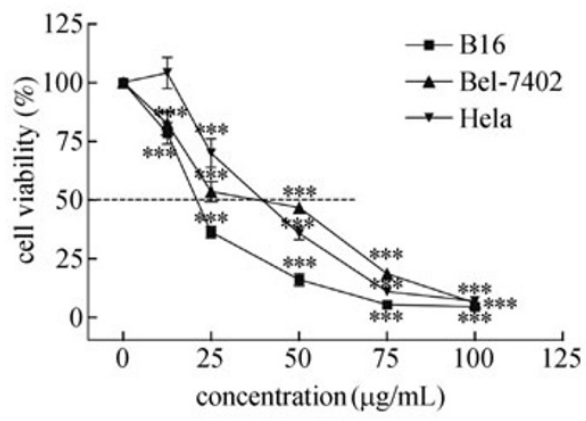

B

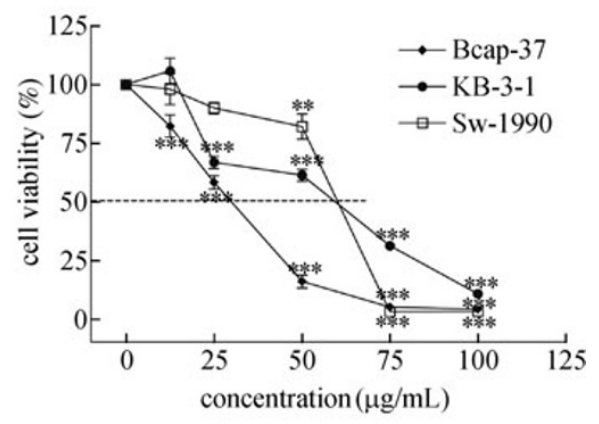

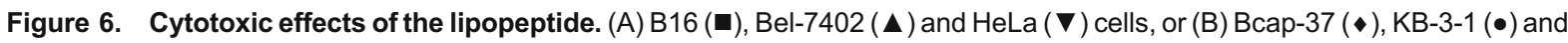
Sw-1990 ( $\square$ ) cells were treated for $24 \mathrm{~h}$ in the presence of the lipopeptide in medium. Cytotoxicity was then determined by MTT assay and was expressed as mean \pm S.D. of three separate experiments $(n=3$ each in the three experiments). (Significant differences from untreated control were indicated by ${ }^{* *} P<0.01$; ${ }^{* * *} P<0.001$.) 
$60 \mu \mathrm{mol} / \mathrm{L}$ have potential cytotoxic effects on different tumor cells. For normal cells, the $50 \%$ cytotoxic concentration $\left(\mathrm{CC}_{50}\right)$ value of antimicrobial lipopeptides (surfactin and fengycin) for the Porcine Kidney (PK-15) cells was $32.87 \mu \mathrm{mol} / \mathrm{L}$ (Huang et al., 2006). The present study showed that the $\mathrm{IC}_{50}$ value for Hacat cells was $100 \mu \mathrm{g} / \mathrm{mL}$, which was larger than those for other tested tumor cells. This confirmed a good toxic selectivity of the lipopeptide on tumor cells such as Bcap-37 cells.

Recently, surfactin has been reported to induce the apoptosis of LoVo (human colon carcinoma cell line) and MCF-7 (human breast cancer cell line) cancer cells, and the mechanisms of surfactin induced apoptosis on cancer cell lines have been investigated on the molecular level (Kim et al., 2007; Cao et al., 2009a, b, c, 2010). For example, the apoptosis of LoVo cells induced by surfactin was mediated by inhibiting extracellular-related protein kinase and phosphoinositide 3-kinase/akt activation, as assessed by phosphorylation levels (Kim et al., 2007). It was reported that the apoptosis effects of surfactin on MCF-7 cell lines were associated with caspase-3 (Cao et al., 2009b). It also revealed that surfactin induced accumulation of the tumor suppressor p53 and cyclin kinase inhibitor p21waf1/cip1, and inhibited the activity of the G2-specific kinase, cyclin B1/ p34cdc2, and the elevation of $\left[\mathrm{Ca}^{2+}\right]$ i may play an important role in the apoptosis of MCF-7 (Cao et al., 2009a). Surfactin also induces apoptosis of MCF-7 cell lines through a ROS/ JNK-mediated mitochondrial/caspase pathway (Cao et al., 2010). Our results that lipopeptides inhibited the growth of Bcap-37 cells by inducing apoptosis were consistent with the findings of Kim (2007) and other authors (Wang et al., 2007). It is worthy to note that surfactin inhibits many enzymes or lipopolysaccharides that are located in the cellular membrane. At the same time, surfactin is a powerful biosurfactant that may accumulate at the interface and interact with cell membranes. In the present study, we therefore focused on the effects of surfactin on the cellular fatty acid composition of membranes to elucidate its apoptosis mechanisms. We hypothesized that lipopeptides exert their inhibitory effects by interaction with membrane or cellular fatty acids as lipopeptides can interact with membrane phospholipids and penetrate into the membrane in a concentration dependent relationship (Carrillo et al., 2003; Heerklotz and Seelig, 2007). Our experiments showed that the composition of cellular fatty acids was influenced by lipopeptides. This may be due to the disturbing effects of lipopeptides on the cell membranes, resulting in the observed change in lipid composition of tumor cells. Moreover, the unsaturated degree of fatty acids of Bcap-37 cell membrane lipids also decreased with increasing concentration of lipopeptides. It is well known that the unsaturation degree is associated with the phase transition and fluidity of membrane lipids (Howlett and Avery, 1997). It has also been reported that an increase in the relative proportion of saturated fatty acids in the membrane can make cancer cells more susceptible to cryodamage (Rakheja et al., 2005). These results lead to the conclusion that lipopeptides exert an inhibitory effect on tumor cells by disturbing the lipid composition, which sensitizes the tumor cells.

It has been shown that fatty acid composition of specific lipids may be important in the tumor cells that are resistant to killing agents (Schlager et al., 1978). Different tumor cells have different saturated cellular fatty acids, which may account for their differential sensitivities. For example, the unsaturated index of B16 (Ando et al., 2006), Bel-7402 (Qi et al., 2007), Hela (Geyer et al., 1962) and KB (Pelz et al., 2006) cells (Table 2 ) are $74.1 \%, 73.5 \%, 90.4 \%$ and $63.0 \%$, respectively. Despite that fact that other lipids, such as glycolipds, are also included in the membranes of tumor cells, the different fatty acid composition of different tumor cells becomes a reasonable explanation of their different $I_{50}$ values.

Table 2 The fatty acid compositions of different tumor cells cultured in RPMI1640 medium

\begin{tabular}{lccccc}
\hline fatty acid & \multicolumn{5}{c}{ composition percentage (\%) } \\
\cline { 2 - 6 } & B16 & Bcap-37 & Bel-7402 & Hela & KB \\
\hline $\mathrm{C}_{14: 0}$ & 4.2 & & 3.4 & 1 & 2.8 \\
$\mathrm{C}_{15: 0}$ & & 0.58 & & & \\
$\mathrm{C}_{16: 0}$ & 28.8 & 49.3 & 24 & 18 & 16.5 \\
$\mathrm{C}_{16: 1}$ & 8.6 & 2.2 & & 5 & 16.6 \\
$\mathrm{C}_{17: 0}$ & & 0.36 & & & \\
$\mathrm{C}_{18: 0}$ & 10.1 & 20.4 & 28.9 & 12 & \\
$\mathrm{C}_{18: 1}$ & 29.6 & 21.6 & 16.1 & 30 & 16.3 \\
$\mathrm{C}_{18: 2}$ & 1.5 & & 25.5 & 25 & \\
$\mathrm{C}_{20: 0}$ & & 0.55 & & & \\
$\mathrm{C}_{20: 1}$ & & 0.86 & & & \\
$\mathrm{C}_{20: 4}$ & 6.2 & 0.84 & 1.5 & & \\
$\mathrm{C}_{21: 0}$ & & & & \\
$\mathrm{C}_{22: 0}$ & & 0.72 & & \\
$\mathrm{C}_{22: 1}$ & & 0.31 & & \\
$\mathrm{C}_{24: 0}$ & & 0.48 & & \\
$\mathrm{C}_{24: 1}$ & & 0.89 & & \\
$\mathrm{UI}_{(\%)}$ & 74.1 & 26.7 & 73.5 & 90.4 & \\
\hline
\end{tabular}

In this paper, the cytotoxic activity of $\mathrm{C}_{15}$-lipopeptide on Bcap-37 cells exerted mainly above (Fig. 2A). The CMC value of $\mathrm{C}_{15}$-lipopeptide was similar to that of other homologs, such as $\mathrm{C}_{13}$-lipopeptides and $\mathrm{C}_{14}$-lipopeptides, so it could be possible that the cytotoxicity of these lipopeptides was related to a particular concentration. This correlation was in accordance with effects of lipopeptides on blood cells in our previous work (Liu et al., 2008). In addition, lipopeptides with different concentrations exerted different effects on tumor cell viability (Fig. 2C). At low concentration, the lipopeptides 
exerted some cytotoxicity but this activity did not persist; the inhibited tumor cells were not killed and were able to proliferate, resulting in increasing cell viability with increased treatment time (Fig. 2C). However, at a high concentration $(75 \mu \mathrm{g} / \mathrm{mL})$, most tumor cells were killed by lipopeptides and did not proliferate with increased treatment time (Fig. 2C and 2D). This indicates there was a threshold concentration for maximum cytotoxicity activity. Furthermore, based on the CMC value, the lipopeptide was a good surface active compound, and we predicted that the surface activity of lipopeptide may be important in its interaction with tumor cell membranes or membrane binding proteins (Fig. 2B).

Our present results (Fig. 2) showed an important role of hydrophobic nature of lipopeptides in their antitumor activities. When the lipopeptide molecule penetrates into the outer sheet of the lipid bilayer, its fatty acid chain interacts with the acyl chains of the phospholipids while its headgroup has affinity to the polar heads of the lipids. It has been shown that surfactin penetration is promoted by longer lipopeptide chain length (Eeman et al., 2006). The data suggested that particularly high hydrophobic lipopeptides have an increased cytotoxic activity on cells (Deleu et al., 2003; Dufour et al., 2005). Furthermore, the significant difference of cytotoxicity in Fig. $2 \mathrm{C}$ revealed that the effects of hydrophobic nature at high concentrations were more important than those at low concentrations, which in turn suggested that micelles formed by lipopeptides were key factors in their antitumor activity.

Our conclusion was that lipopeptides exerted their cytotoxicity on tumor cells in a dose-dependent manner until a threshold was reached and the tumor cells no longer maintained the structure of their membrane, which resulted in cell apoptosis. It is worthy to note that in addition to the surface active properties of lipopeptides, the free carboxyl acid residues in structures of lipopeptides play an important role in its effects on the alkaline phosphatase (Bortolato et al., 1997). Moreover, the lipopeptide can change the conformation of plasminogen (Kikuchi and Hasumi, 2002). These activities may also contribute to the further interaction of lipopeptide with enzymes of tumor cell membranes. Whether the lipopeptides influence on fatty acid composition is correlated to their effects on the fatty acid synthase will be an interesting topic.

\section{MATERIALS AND METHODS}

\section{Chemicals}

Cyclic lipopeptides (MW1007, 1021, 1035, which were $\mathrm{C}_{13}$-lipopeptide, $\mathrm{C}_{14}$-lipopeptide and $\mathrm{C}_{15}$-lipopeptide, respectively) were isolated from Bacillus subtilis HSO121 according to previous isolation and purification procedures (Liu et al., 2007, 2008; Haddad et al., 2008). The structures of the $\mathrm{C}_{13}$-lipopeptide, $\mathrm{C}_{14}$-lipopeptide and $\mathrm{C}_{15^{-}}$ lipopeptide were shown in Fig. 7. The lipopeptides were first dissolved in dimethyl sulfoxide (DMSO) with a final DMSO concentration of $0.1 \%(v / v)$ for each sample. Previous experiments have shown that
DMSO at this concentration did not influence cellular activities (Ye et al., 2004). The control cells were treated with vehicle alone, $0.1 \%(v /$ v). MTT was purchased from Bioseen Technology, Inc; Rosewell Park Memorial Institute (RPMI) 1640 medium was purchased from GIBCO BRL, Grand Island, NY, USA; Fetal bovine serum (FBS) was purchased from Hangzhou Sijiqing Co., Ltd; Phosphate buffered saline (PBS, pH 7.4) was composed of: $\mathrm{NaCl} 8.0 \mathrm{~g}, \mathrm{KCl} 0.2 \mathrm{~g}$, $\mathrm{Na}_{2} \mathrm{HPO}_{4} \cdot 12 \mathrm{H}_{2} \mathrm{O} 3.49 \mathrm{~g}, \mathrm{KH}_{2} \mathrm{PO}_{4} 0.2 \mathrm{~g}$, per liter of double distilled water.

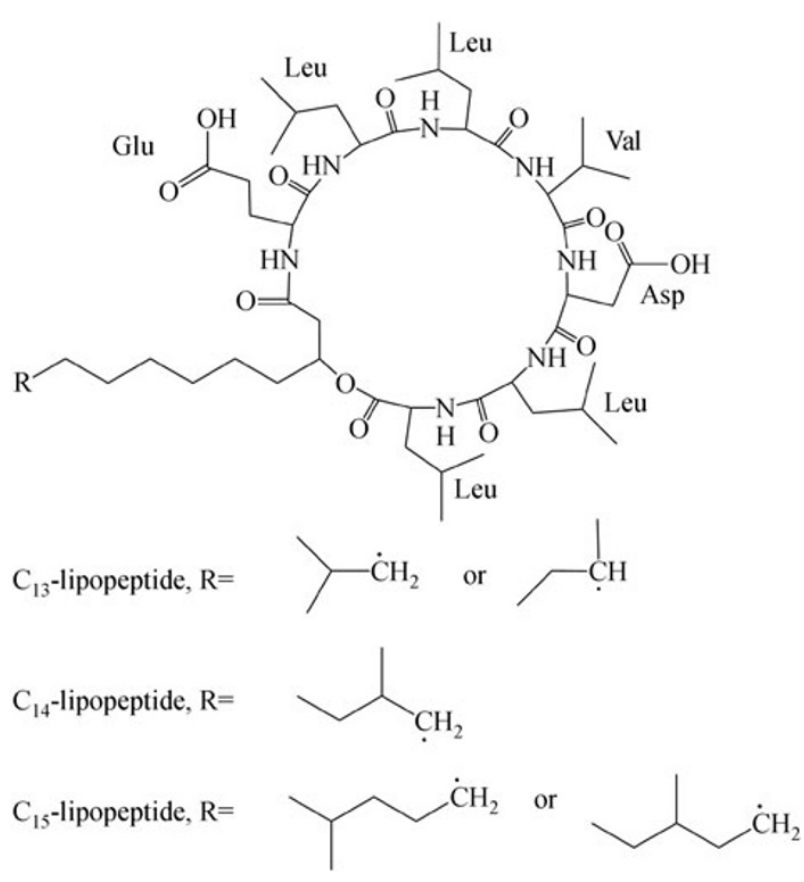

Figure 7. The chemical structures of lipopeptides.

\section{Cell lines and culture conditions}

The cancer cell lines included human oral epidermoid carcinoma cell line (KB-3-1), human breast cancer cell line (Bcap-37), human liver cancer cell line (Bel-7402), human pancreas cancer cell line (Sw1990), human cervix uteri cell line (HeLa), and rat melanoma cell line (B16). The normal cell line was human keratinocytes cell line (HaCaT). All cells were purchased from the Chinese Type Culture Collection (Shanghai Institute of Cell Biology, Chinese Academy of Science, Shanghai, China). They were cultured in RPMI 1640 medium with $10 \%$ FBS, penicillin $(100 \mathrm{U} / \mathrm{mL})$ and streptomycin $(100 \mu \mathrm{g} / \mathrm{mL})$. All cells were incubated at $37^{\circ} \mathrm{C}$ with $5 \% \mathrm{CO}_{2}$ in an air atmosphere.

\section{Cytotoxicity assay}

The MTT colorimetric assay was performed as described by Mosman (Mosmann, 1983). KB-3-1, Bcap-37, Bel-7402, SW-1990, HeLa and B16 cells were placed in 96-well culture plates $\left(10^{4}\right.$ cells/well $)$ and allowed to attach for $24 \mathrm{~h}$ before treatment. The cells were treated with lipopeptide ranging from 12.5 to $100 \mu \mathrm{g} / \mathrm{mL}$ or without the 
lipopeptide (vehicle control, $0.1 \%$ DMSO). Each experiment was repeated in triplicate. The lipopeptide cytotoxicity activities on the cell lines were measured after $24 \mathrm{~h}$ of culture using the MTT assay. Absorbance in control and lipopeptide-treated wells was measured at $570 \mathrm{~nm}$, with a reference wavelength of $655 \mathrm{~nm}$, using an Automated Microplate Reader (Microplate Reader, 550 Bio-Rad, USA). The cytotoxicity of the lipopeptide was expressed as $I_{50}$ (inhibitory concentration of $50 \%$ cytotoxicity), which was extrapolated from linear regression analysis of the experimental data.

\section{Surface tension measurement}

The lipopeptides were dissolved in DMSO and then diluted using PBS. The surface tension was measured at $25.0^{\circ} \mathrm{C}$ with a DCA 315 series system (Thermo-Cahn Instruments, Inc. USA).

\section{Fluorescent staining of the nuclei of Bcap-37 cells}

Bcap-37 cells from exponentially growing cultures were seeded in 24well culture plates and were allowed to attach for $24 \mathrm{~h}$ before treatment. The cells were treated for $24 \mathrm{~h}$ with 12.5, 25, 50, 75 and $100 \mu \mathrm{g} / \mathrm{mL}$ lipopeptides or with a vehicle control. After treatment, cells were washed two times with $\mathrm{PBS}$, and were fixed with $\mathrm{MeOH}-\mathrm{HAc}$ $(3: 1, v / v)$ for $10 \mathrm{~min}$ at $4^{\circ} \mathrm{C}$. Cells were stained with Hoechst 33258 $(5 \mu \mathrm{g} / \mathrm{mL}$ in PBS) for $10 \mathrm{~min}$ at room temperature and then examined in a Leica DMIRB fluorescent microscope at $356 \mathrm{~nm}$.

\section{Flow cytometric assay for Bcap-37 cells}

Flow cytometric analysis of the Bcap-37 cell cycle was performed according to the method described previously (Walker et al., 1993). The cells were collected by centrifugation at $1000 \mathrm{rpm}$ on a TGL-802B centrifuge (ShangHai Anting Scientific Instrument Factory) for $5 \mathrm{~min}$ and thoroughly rinsed with PBS. The pellets were re-suspended in ice-cold $70 \%$ ethanol and fixed at $-20^{\circ} \mathrm{C}$ overnight $(12 \mathrm{~h})$. The fixed solution was washed three times with PBS and centrifuged (1000 rpm for $5 \mathrm{~min}$ ). The cell pellets were re-suspended in $500 \mu \mathrm{L}$ PBS containing $50 \mu \mathrm{L}$ of $5 \mathrm{mg} / \mathrm{mL}$ RNaseA and stained with $10 \mu \mathrm{L}$ of $5 \mathrm{mg} / \mathrm{mL}$ propidium iodide ( $\mathrm{PI}$ ), then incubated in a black box at room temperature for $30 \mathrm{~min}$. Cells were analyzed using a FACScan (Becton Dickinson, USA) with Cell Fit software. Cells that have lost DNA due to the apoptosis will take up less stain and will appear to the left of the G1 peak (sub-G1) (Gorczyca et al., 1993; Gong et al., 1994; Elstein et al., 1995).

\section{Fatty acid analysis by GC/MS}

The fatty acid composition of Bcap-37 cell membranes was determined after the cells were treated for $24 \mathrm{~h}$ with $30 \mu \mathrm{g} / \mathrm{mL}$ or $60 \mu \mathrm{g} / \mathrm{mL}$ lipopeptide, or were a control. The digested and undigested cells were collected by centrifugation for $5 \mathrm{~min}$ at $2000 \mathrm{rpm}$ on a TGL80-2B centrifuge (ShangHai Anting Scientific Instrument Factory), and then washed three times in PBS. The total lipids were extracted from the cells using the procedure of Bligh and Dyer (Bligh and Dyer, 1959). The preparation of fatty acid methyl esters was divided into four steps: soaping with $3 \mathrm{~mol} / \mathrm{L} \mathrm{NaOH}$ and methanol $(1: 1, v / v)$ at $65^{\circ} \mathrm{C}$ for $30 \mathrm{~min}$; esterification with $\mathrm{H}_{2} \mathrm{SO}_{4} / \mathrm{MeOH}(1: 10, v / v)$ at $55^{\circ} \mathrm{C}$ for $6 \mathrm{~h}$; extraction with ether; and evaporation under a stream of nitrogen at ambient temperature. The extracted fatty acid methyl ester was subjected to gas chromatography/mass spectrometry (instrument model 6890N-5975; Hewlett-Packard Co., Avondale, USA) with HP 3392A integrator using a HP-5MS capillary column $(30.0 \mathrm{~m} \times$ $0.25 \mathrm{~mm} \times 0.25 \mu \mathrm{m}$ nominal) packed with $5 \%$ phenyl methyl siloxane. One microliter of the extract (dissolved in $0.5 \mathrm{~mL}$ methanol) was injected for analysis by the 7683B series injector. The column oven temperature started at $80^{\circ} \mathrm{C}$ for $3 \mathrm{~min}$, then reached $260^{\circ} \mathrm{C}$ at a rate of $10^{\circ} \mathrm{C} / \mathrm{min}$ and was maintained at $260^{\circ} \mathrm{C}$ for $10 \mathrm{~min}$. Fatty acid methyl esters were identified by searching the standard MS library.

\section{Statistical analysis}

The scientific statistic software GraphPad Instat version 3.06 was used to evaluate the significance of differences between groups. Each experimental value was expressed as the mean \pm standard deviation (S.D.). Comparisons between groups were done using a one-way ANOVA followed by a Student-Newman-Keul's test, and the criterion of statistical significance was taken as ${ }^{* \star} P<0.01$ or ${ }^{* * *} P<$ 0.001 .

\section{ACKNOWLEDGEMENTS}

The authors are very grateful for the technical support provided by Xin $\mathrm{Ye}$ in the antitumor experiment. They also would like to thank Haian Fu and Elizabeth Ashforth for critical reading and helpful discussions. This work was supported in part by grants from the National Natural Science Foundation of China (Nos. 50574040, 30700015), the Ministry of Science and Technology of China (2007CB707801), Shanghai Science and Technology Commission (No. 071607014), China Postdoctoral Science Foundation (20080440545), the National Programs for High Technology Research and Development Program (863 Program) (No. 2006AA09Z402), and Key Project of International Cooperation (2007DFB31620). L.Z. is an awardee for Hundred Talents Program.

\section{ABBREVIATIONS}

CMC, critical micelle concentration; FBS, fetal bovine serum; GC, gas chromatography; MTT, 3-(4, 5-dimethylthiazol-2-yl)-2, 5- diphenyl

\section{REFERENCES}

Ando, H., Wen, Z.M., Kim, H.Y., Valencia, J.C., Costin, G.E., Watabe, H., Yasumoto, K., Niki, Y., Kondoh, H., Ichihashi, M., et al. (2006). Intracellular composition of fatty acid affects the processing and function of tyrosinase through the ubiquitin-proteasome pathway. Biochem J 394, 43-50.

Arima, K., Kakinuma, A., and Tamura, G. (1968). Surfactin, a crystalline peptidelipid surfactant produced by Bacillus subtilis: isolation, characterization and its inhibition of fibrin clot formation. Biochem Biophys Res Commun 31, 488-494.

Bligh, E.G., and Dyer, W.J. (1959). A rapid method of total lipid extraction and purification. Can J Biochem Physiol 37, 911-917.

Bonmatin, J.M., Laprévote, O., and Peypoux, F. (2003). Diversity among microbial cyclic lipopeptides: iturins and surfactins. Activitystructure relationships to design new bioactive agents. Comb 
Chem High Throughput Screen 6, 541-556.

Bortolato, M., Besson, F., and Roux, B. (1997). Inhibition of alkaline phosphatase by surfactin, a natural chelating lipopeptide from Bacillus subtilis. Biotechnol Lett 19, 433-435.

Cao, X., Wang, A.H., Jiao, R.Z., Wang, C.L., Mao, D.Z., Yan, L., and Zeng, B. (2009a). Surfactin induces apoptosis and G(2)/M arrest in human breast cancer MCF-7 cells through cell cycle factor regulation. Cell Biochem Biophys 55, 163-171.

Cao, X.H., Liao, Z.Y., Wang, C.L., Cai, P., Yang, W.Y., Lu, M.F., and Huang, G.W. (2009b). Purification and antitumour activity of a lipopeptide biosurfactant produced by Bacillus natto TK-1. Biotechnol Appl Biochem 52, 97-106.

Cao, X.H., Liao, Z.Y., Wang, C.L., Yang, W.Y., and Lu, M.F. (2009c). Evaluation of a lipopeptide biosurfactant from Bacillus natto Tk-1 as a potential source of anti-adhesive. Antimicrobial and Antitumor Activities. Braz J Microbiol 40, 373-379.

Cao, X.H., Wang, A.H., Wang, C.L., Mao, D.Z., Lu, M.F., Cui, Y.Q., and Jiao, R.Z. (2010). Surfactin induces apoptosis in human breast cancer MCF-7 cells through a ROS/JNK-mediated mitochondrial/ caspase pathway. Chem Biol Interact 183, 357-362.

Carrillo, C., Teruel, J.A., Aranda, F.J., and Ortiz, A. (2003). Molecular mechanism of membrane permeabilization by the peptide antibiotic surfactin. Biochim Biophys Acta 1611, 91-97.

Dai, R.J., Phillips, R.A., Zhang, Y., Khan, D., Crasta, O., and Ahmed, S.A. (2008). Suppression of LPS-induced Interferon-gamma and nitric oxide in splenic lymphocytes by select estrogen-regulated microRNAs: a novel mechanism of immune modulation. Blood 112, 4591-4597.

Deleu, M., Bouffioux, O., Razafindralambo, H., Paquot, M., Hbid, C., Thonart, P., Jacques, P., and Brasseur, R. (2003). Interaction of surfactin with membranes: a computational approach. Langmuir 19, 3377-3385.

Dufour, S., Deleu, M., Nott, K., Wathelet, B., Thonart, P., and Paquot, M. (2005). Hemolytic activity of new linear surfactin analogs in relation to their physico-chemical properties. Biochim Biophys Acta 1726, 87-95.

Eeman, M., Berquand, A., Dufrêne, Y.F., Paquot, M., Dufour, S., and Deleu, M. (2006). Penetration of surfactin into phospholipid monolayers: nanoscale interfacial organization. Langmuir 22, 11337-11345.

Elstein, K.H., Thomas, D.J., and Zucker, R.M. (1995). Factors affecting flow cytometric detection of apoptotic nuclei by DNA analysis. Cytometry 21, 170-176.

Geiser, F., McAllan, B.M., and Kenagy, G.J. (1994). The degree of dietary fatty acid unsaturation affects torpor patterns and lipid composition of a hibernator. J Comp Physiol B 164, 299-305.

Geyer, R.P., Bennett, A., and Rohr, A. (1962). Fatty acids of the triglycerides and phospholipids of HeLa cells and strain L fibroblasts. J Lipid Res 3, 80-83.

Gong, J., Traganos, F., and Darzynkiewicz, Z. (1994). A selective procedure for DNA extraction from apoptotic cells applicable for gel electrophoresis and flow cytometry. Anal Biochem 218, 314-319.

Gorczyca, W., Gong, J., and Darzynkiewicz, Z. (1993). Detection of DNA strand breaks in individual apoptotic cells by the in situ terminal deoxynucleotidyl transferase and nick translation assays. Cancer Res 53, 1945-1951.

Grau, A., Gómez Fernández, J.C., Peypoux, F., and Ortiz, A. (1999). A study on the interactions of surfactin with phospholipid vesicles.
Biochim Biophys Acta 1418, 307-319.

Haddad, N.I.A., Liu, X.Y., Yang, S.Z., and Mu, B.Z. (2008). Surfactin isoforms from Bacillus subtilis HSO121: separation and characterization. Protein Pept Lett 15, 265-269.

Hagve, T.A. (1988). Effects of unsaturated fatty acids on cell membrane functions. Scand J Clin Lab Invest 48, 381-388.

Heerklotz, H., and Seelig, J. (2001). Detergent-like action of the antibiotic peptide surfactin on lipid membranes. Biophys $\mathrm{J} 81$, 1547-1554.

Heerklotz, H., and Seelig, J. (2007). Leakage and lysis of lipid membranes induced by the lipopeptide surfactin. Eur Biophys $\mathrm{J} 36$, 305-314.

Howlett, N.G., and Avery, S.V. (1997). Relationship between cadmium sensitivity and degree of plasma membrane fatty acid unsaturation in Saccharomyces cerevisiae. Appl Microbiol Biotechnol 48, 539-545.

Huang, X.Q., Lu, Z.X., Zhao, H.Z., Bie, X.M., Xia, L.F., and Yang, S.J. (2006). Antiviral activity of antimicrobial lipopeptide from Bacillus subtilis fmbj against Pseudorabies Virus, Porcine Parvovirus, Newcastle Disease Virus and Infectious Bursal Disease Virus in Vitro. Int J Pept Res Ther 12, 373-377.

Kameda, Y., Oira, S., Matsui, K., Kanatomo, S., and Hase, T. (1974). Antitumor activity of bacillus natto. V. Isolation and characterization of surfactin in the culture medium of Bacillus natto KMD 2311. Chem Pharm Bull (Tokyo) 22, 938-944.

Kikuchi, T., and Hasumi, K. (2002). Enhancement of plasminogen activation by surfactin $\mathrm{C}$ : augmentation of fibrinolysis in vitro and in vivo. Biochim Biophys Acta 1596, 234-245.

Kim, S.Y., Kim, J.Y., Kim, S.H., Bae, H.J., Yi, H., Yoon, S.H., Koo, B. S., Kwon, M., Cho, J.Y., Lee, C.E., et al. (2007). Surfactin from Bacillus subtilis displays anti-proliferative effect via apoptosis induction, cell cycle arrest and survival signaling suppression. FEBS Lett 581, 865-871.

Kuo, M.T. (2009). Redox regulation of multidrug resistance in cancer chemotherapy: molecular mechanisms and therapeutic opportunities. Antioxid Redox Signal 11, 99-133.

Liu, X.Y., Haddad, N.I.A., Yang, S.Z., and Mu, B.Z. (2007). Structural characterization of eight cyclic lipopeptides produced by Bacillus subtilis HSO121. Protein Pept Lett 14, 766-773.

Liu, X.Y., Yang, S.Z., and Mu, B.Z. (2008). Isolation and characterization of a $\mathrm{C}_{12}$-lipopeptide produced by Bacillus subtilis HSO 121. J Pept Sci 14, 864-875.

Marsh, S., and McLeod, H.L. (2007). Pharmacogenetics and oncology treatment for breast cancer. Expert Opin Pharmacother 8, 119-127.

Menendez, J.A., Vellon, L., and Lupu, R. (2005). Targeting fatty acid synthase-driven lipid rafts: a novel strategy to overcome trastuzumab resistance in breast cancer cells. Med Hypotheses 64, 997-1001.

Michel, V., and Bakovic, M. (2007). Lipid rafts in health and disease. Biol Cell 99, 129-140.

Mosmann, T. (1983). Rapid colorimetric assay for cellular growth and survival: application to proliferation and cytotoxicity assays. J Immunol Methods 65, 55-63.

Pelz, K., Hopfener, K., Wiedmann-Al-Ahmad, M., Jahnke, H., Wittmer, A., and Otten, J.E. (2006). Differences in the fatty acid composition of KB-cells and gingival keratinocytes is culture medium additive dependent. Biomed Chromatogr 20, 870-880. 
Qi, L.F., Xu, Z.R., and Chen, M.L. (2007). In vitro and in vivo suppression of hepatocellular carcinoma growth by chitosan nanoparticles. Eur J Cancer 43, 184-193.

Rakheja, D., Kapur, P., Hoang, M.P., Roy, L.C., and Bennett, M.J. (2005). Increased ratio of saturated to unsaturated $C 18$ fatty acids in colonic adenocarcinoma: implications for cryotherapy and lipid raft function. Med Hypotheses 65, 1120-1123.

Savage, P.B., Li, C., Taotafa, U., Ding, B., and Guan, Q. (2002). Antibacterial properties of cationic steroid antibiotics. FEMS Microbiol Lett 217, 1-7.

Schlager, S.I., Ohanian, S.H., and Borsos, T. (1978). Correlation between the ability of tumor cells to incorporate specific fatty acids and their sensitivity to killing by a specific antibody plus guinea pig complement. J Natl Cancer Inst 61, 931-934.

Sheppard, J.D., Jumarie, C., Cooper, D.G., and Laprade, R. (1991). Ionic channels induced by surfactin in planar lipid bilayer membranes. Biochim Biophys Acta 1064, 13-23.

Singletary, S.E. (2008). Breast cancer management: the road to today. Cancer 113, 1844-1849.

Vaara, M. (1992). Agents that increase the permeability of the outer membrane. Microbiol Rev 56, 395-411.

Vollenbroich, D., Pauli, G., Özel, M., and Vater, J. (1997). Antimycoplasma properties and application in cell culture of surfactin, a lipopeptide antibiotic from Bacillus subtilis. Appl Environ Microbiol 63, 44-49.

Walker, P.R., Kwast-Welfeld, J., Gourdeau, H., Leblanc, J., Neugebauer, W., and Sikorska, M. (1993). Relationship between apoptosis and the cell cycle in lymphocytes: roles of protein kinase C, tyrosine phosphorylation, and AP1. Exp Cell Res 207, 142-151.

Wang, C.L., Ng, T.B., Yuan, F., Liu, Z.K., and Liu, F. (2007). Induction of apoptosis in human leukemia K562 cells by cyclic lipopeptide from Bacillus subtilis natto T-2. Peptides 28, 1344-1350.

Ye, C.L., Liu, J.W., Wei, D.Z., Lu, Y.H., and Qian, F. (2004). In vitro anti-tumor activity of 2 ', 4 '-dihydroxy-6'-methoxy-3',5'dimethylchalcone against six established human cancer cell lines. Pharmacol Res 50, 505-510. 